\title{
Keeping up with the Jones case: Establishing constructive trusts in 'sole legal owner' scenarios
}

\section{Brian Sloan*}

College Lecturer \& Fellow in Law, Robinson College, Cambridge

bds26@,cam.ac.uk

\section{INTRODUCTION}

The flood of litigation predictable following the decision of the Supreme Court in Jones $v$ Kernott $^{1}$ has occurred. Much could be said about the meaning of the Court's approach to the quantification of beneficial interests under common intention constructive trusts in cases where both parties to a personal relationship appear on the legal title of a shared home. ${ }^{2}$ The focus of this article, however, is a situation with which Jones was not directly concerned but for which it could have profound implications. That scenario, beloved of property law and family law examiners but also of immense practical importance for parting couples who

\footnotetext{
${ }^{*}$ Earlier versions of this article were presented at a Cambridge Private Law Seminar in February 2013, and at a symposium entitled 'Trusts of the Family Home and the Frontiers of Family Property: Domestic and Comparative Perspectives' at Durham Law School in April 2013 (sponsored by the Modern Law Review). The author is very grateful to Amy Goymour and Andrew Hayward for organising the respective events, and to the attendees, Philippa Daniels and the anonymous referees for their helpful comments, though all errors are his own.

${ }^{1}$ [2011] UKSC 53, [2012] 1 AC 776.

${ }^{2}$ See, eg, M Pawlowski 'Imputed intention and joint ownership - a return to common sense: Jones v Kernott' [2012] Conveyancer \& Property Lawyer 149; M Yip 'The rules applying to unmarried cohabitants' family home: Jones v Kernott' [2012] Conveyancer \& Property Lawyer 159; J Mee 'Jones v Kernott: Inferring and imputing in Essex’ [2012] Conveyancer \& Property Lawyer 167.
} 
entered neither a marriage nor a civil partnership, is one where there is only one legal owner of a home and the other party to a cohabiting relationship seeks to establish that he has an equitable interest in the home under a common intention constructive trust.

This article examines the considerable number of common intention constructive trust cases that have been decided since the judgments in Jones $v$ Kernott were handed down. ${ }^{3}$ It focuses particularly on the judicial treatment of the establishment (as distinct from the quantification) of a beneficial interest by a legal non-owner in a domestic context. The second part summarises the recent history of claims by legal non-owners and examines the possible implications of Jones for such claims, before the main part of the article analyses the early judicial response to the case. The article argues that while judges have mostly accepted that Jones is relevant to sole-owner cases, they have had few opportunities (and taken fewer) to allow novel outcomes in the light of it as yet. If this produces a conservative approach it is normatively problematic for cohabitants who make indirect or non-financial contributions to shared lives and remain without statutory property and financial provision on relationship breakdown. This is true even if the constructive trust is not the most appropriate method through which to produce a more normatively justifiable outcome, and even if caution is appropriate in the light of stare decisis.

\section{LEGAL NON-OWNERS, THE HOUSE OF LORDS AND THE SUPREME COURT}

\footnotetext{
${ }^{3}$ Jones was also cited in Dunn v Institute of Cemetery and Crematorium Management [2012] ICR 941 (EAT) at [41] (Judge McMullen QC) to illustrate the differences in the legal treatment of married as compared to unmarried couples; and in $V v V$ [2011] EWHC 3230 (Fam), [2012] 1 FLR 1315 at [81] (Charles J) to emphasise the dangers of treating judicial 'concepts, guidance or principles' as though they had statutory force. In $Z v A$ (Financial Remedies: Overseas Divorce) [2012] EWHC 467 (Fam), [2012] 2 FLR 667 its principles on inference were used to ascertain whether the parties had an understanding that they would make no claims from each other in the event of divorce.
} 
While credit for developing the common intention constructive trust is generally given to Lord Diplock following his speech in Gissing $v$ Gissing ${ }^{4}$ in the light of Pettitt $v$ Pettitt, ${ }^{5}$ it has been the subject of 'a long stream of authority ${ }^{\prime 6}$ in both the House of Lords ${ }^{7}$ and the Court of Appeal $^{8}$ in addition to its more recent trip to the Supreme Court in Jones $v$ Kernott. ${ }^{9}$ It has been described as 'a specific jurisprudential response' to problems of ownership relating to family homes, ${ }^{10}$ 'driven by policy considerations and the special facts that normally apply in the dealings between those living in an intimate relationship', ${ }^{11}$ and its development has been branded a 'familialisation' of property law. ${ }^{12}$ While judges are able to reallocate the property of married couples on divorce (and civil partners in the equivalent predicament) on the basis of a statutory discretion, ${ }^{13}$ it is well known in the academy that there is no analogous legislation in the case of unmarried couples whose relationship has broken down while both

\footnotetext{
${ }^{4}$ [1971] AC 886 HL.

${ }^{5}$ [1970] AC 777 HL.

${ }^{6}$ Crown Prosecution Service v Piper [2011] EWHC 3570 (Admin) at [7] (Holman J).

${ }^{7}$ Lloyds Bank plc v Rosset [1991] 1 AC 107 HL, Stack v Dowden [2007] UKHL 17, [2007] 2 AC 432.
}

${ }^{8}$ See, eg, Eves v Eves [1975] 1 WLR 1338 CA; Oxley v Hiscock [2004] EWCA Civ 546, [2005] Fam. 211; Morris v Morris [2008] EWCA Civ 257, [2008] Family Law 521; James v Thomas [2007] EWCA Civ 1212, [2008] 1 FLR 1598; Fowler v Barron [2008] EWCA Civ 377, [2008] 2 FLR 831; Laskar v Laskar [2008] EWCA Civ 347, [2008] 1 WLR 2695.

${ }^{9}$ [2011] UKSC 53.

${ }^{10}$ Crossco No 4 Unlimited v Jolan Ltd [2011] EWCA Civ 1619, [2012] 2 All ER 754 at [85] (Etherton LJ).

${ }^{11}$ Crossco No 4 Unlimited [2011] EWCA Civ 1619 at [85].

${ }^{12}$ See, eg, A Hayward “"Family property” and the process of "familialisation” of property law' [2012] Child \& Family Law Quarterly 284.

\footnotetext{
${ }^{13}$ Matrimonial Causes Act 1973, Pt II; Civil Partnership Act 2004, Sch 5. Cf. Marriage (Same Sex Couples) Act 2013, s 11.
} 
parties are still alive. ${ }^{14}$ The need for such legislation is a hotly debated question that cannot be conclusively resolved by this article. ${ }^{15}$

Whatever its drawbacks, and whatever the perceived need for statutory reform, the common intention constructive trust potentially enables an unmarried cohabitant to assert that the equitable ownership of the home differs from the legal ownership on the basis of an express or implied common intention between the parties, notwithstanding the absence of an express declaration of trust in his favour. This allows the claimant to avoid the rigidity of a resulting trust analysis, which would allocate fixed shares proportionate to the parties' direct financial contributions to (or possibly financial liability in respect of ${ }^{16}$ the property. Indeed, in Jones the resulting trust was considered to be inappropriate in domestic cases involving

${ }^{14}$ See, eg, Law Commission 'Statement on the Government's Response to the Law Commission Report "Cohabitation: The Financial Consequences of Relationship Breakdown"' (6 September 2011), concerning the current Government's decision not to implement the recommendations contained in Law Commission, Cohabitation: The Financial Consequences of Relationship Breakdown (Law Com No 307, London: HMSO, 2007) during the current Parliament. For a recent comparative discussion, see A Sanders 'Cohabitants in Private Law: Trust, Frustration and Unjust Enrichment in England, Germany and Canada' (2013) 62 International \& Comparative Law Quarterly 628.

${ }^{15}$ See, eg, R Deech 'The case against legal recognition of cohabitation' (1980) 29 International \& Comparative Law Quarterly 480. Probert has suggested that few unmarried couples are left without any property-based legal protection on relationship breakdown: R Probert 'Cohabitation: Current legal solutions' in C O'Cinneide (ed), Current Legal Problems - Volume 62 (Oxford: OUP, 2009) p 341. Cf. Lady Hale's suggestion (in Gow v Grant [2012] UKSC 29, 2013 SC (UKSC) 1 at [47]) that 'a family law remedy such as that proposed by the Law Commission would be less costly and more productive of settlements as well as achieving fairer results than the present law' in England and Wales. See J Miles 'Cohabitation: lessons for the south from north of the border?' [2012] CLJ 492 for discussion of the case, which concerned the Family Law (Scotland) Act 2006, but cf. S Gardner 'Problems in family property' [2013] CLJ 301 for criticism.

${ }^{16}$ See the remarks of Lord Neuberger in Stack $v$ Dowden [2007] UKHL 17 at [117]-[120] and in Laskar v Laskar [2008] EWCA Civ 347 at [27]-[31]. 
family homes. ${ }^{17}$ Detrimental reliance by the claimant was also traditionally required for a constructive trust. While this was not expressly mentioned either by the House of Lords in Stack $v$ Dowden $^{18}$ or the Supreme Court in Jones, it would be difficult to justify the intervention of equity in the absence of such reliance due to the need for some form of unconscionability. It must surely be a vital factor in the court's evaluation of what is 'fair' when imputing a common intention to the parties during the process of quantifying the extent of a party's interest under a constructive trust. ${ }^{19}$ The requirement was sufficiently fundamental that a mere failure to mention it cannot safely be taken as evidence of its demise. Indeed, in the post-Jones Court of Appeal decision in Smith v Bottomley, detrimental reliance was considered to be 'a critical element of [the] claim to a beneficial interest in the properties in question...by way of constructive trust', ${ }^{20}$ and the outcome partly turned on the point. ${ }^{21}$

One of the most difficult aspects of the developing law on the common intention constructive trust is that the two cases most recently decided at the highest judicial level were in substance focused on the quantification of equitable interests held by joint legal owners rather than the establishment of interests. In a sense, the sole legal owner scenario is rather more significant, since it concerns the claim of a legal non-owner who may lack an entitlement altogether while a joint legal owner is unlikely to go away empty-handed.

\footnotetext{
${ }^{17}$ Jones [2011] UKSC 53 at [25], [53] (Lady Hale and Lord Walker). Cf. Lord Neuberger's dissenting speech in Stack [2007] UKHL 17, and Chaudhary v Chaudhary [2013] EWCA Civ 758, [2013] Family Law 1257.

18 [2007] UKHL 17. See, eg, T Etherton 'Constructive trusts and proprietary estoppel: the search for clarity and principle’ [2009] Conveyancer \& Property Lawyer 104 for discussion.

${ }^{19}$ See the text to $\mathbf{5 0}$ below.

${ }^{20}$ [2013] EWCA Civ 953, [2013] 2 P \& CR DG25 at [31] (Sales J). See also, eg, Re Ali [2012] EWHC 2302 (Admin), [2012] Family Law 1324 at [108] (Dobbs J).

${ }^{21}$ See the text to $\mathrm{n} \mathbf{1 4 5}$ below.
} 
Following the 1990 decision of the House of Lords in Lloyds Bank plc $v$ Rosset, $^{22}$ the common intention of shared ownership necessary to prove a constructive trust could be evidenced either by express discussions 'that the property is to be shared beneficially', 'however imperfectly remembered and however imprecise their terms may have been', ${ }^{23}$ or by the implication drawn from 'direct contributions to the purchase price by the partner who is not the legal owner, whether initially or by payment of mortgage instalments'. ${ }^{24}$ In Lord Bridge's infamous words, it was 'at least extremely doubtful whether anything less [would] do', ${ }^{25}$ causing problems with Lees' recent suggestion that any expansion of Lord Bridge's approach is 'not inconsistent' with his comments. ${ }^{26}$ A focus on express discussion or direct financial contributions clearly prejudiced those legal non-owning cohabitants who could not point to express discussions and had made only indirect financial or purely domestic contributions, particularly where those contributions in substance facilitated the acquisition of the equity in the home by the other party to the relationship, ${ }^{27}$ often through the payment of one particular regular bill (ie the mortgage). It also prioritised financial contributions in a manner similar to that widely considered undesirable in the context of the resulting trust,

\footnotetext{
${ }^{22}$ [1991] 1 AC 107.

${ }^{23}$ Rosset [1991] 1 AC 107 at 132 (Lord Bridge).

${ }^{24}$ Rosset [1991] 1 AC 107 at 133 (Lord Bridge).

${ }^{25}$ Rosset [1991] 1 AC 107 at 133. Cf. Le Foe v Le Foe [2001] 2 FLR 970.

${ }^{26}$ K Lees 'Geary v Rankine: Money isn't everything’ [2012] Conveyancer \& Property Lawyer 412 at 417-418.

${ }^{27}$ See, infamously, Burns v Burns [1984] Ch 317 CA, discussed, eg, in J Mee 'Burns v Burns: The Villain of the Piece?' in R Probert, J Herring and S Gilmore (eds) Landmark Cases in Family Law (Oxford: Hart Publishing, 2011). Gardner has asserted with surprising confidence not only that Burns would not be decided in the same way today, but also that 'a modern Mrs Burns would have maybe half the equity in the home, very possibly more': S Gardner 'Problems in Family Property' [2013] CLJ 301 at 306. Cf. Thomson v Humphrey [2009] EWHC 3576 (Ch), [2010] 2 FLR 107 at [29] (Warren J).
} 
albeit with express discussions providing an alternative route to entitlement for some fortunate parties.

It is unclear whether the majority of the House of Lords in Stack $v$ Dowden (decided 17 years after Rosset) were intending to liberalise or restrict the earlier analysis in Rosset. In that 'joint names' case, which generated an inordinate amount of academic commentary, ${ }^{28}$ Lady Hale held that 'at least in the domestic consumer context' ${ }^{29}$ there is a strong presumption that ownership in equity follows the position at law. ${ }^{30}$ This suggests that a legal non-owner who is not a beneficiary under an express trust has to rebut a strong presumption in order to demonstrate that he has any (equitable) interest at all. ${ }^{31}$ That said, the strength of the presumption was undermined by the myriad factors that are said to be relevant to its displacement, at least when quantifying the interest in a 'joint names' case, on the basis of common intention. These were set out at length but non-exhaustively by Lady Hale at paragraph 69 of the Stack decision. ${ }^{32}$ Some of the relevant considerations, including 'the

\footnotetext{
${ }^{28}$ See, eg, M Dixon 'The never-ending story - co-ownership after Stack v Dowden' [2007] Conveyancer \& Property Lawyer 456; M Harding 'Defending Stack v Dowden' [2009] Conveyancer \& Property Lawyer 309; W Swadling 'The common intention constructive trust in the house of lords: an opportunity missed' (2007) 123 LQR 511; R Probert 'Cohabitants and joint ownership: The implications of Stack v Dowden' [2008] Family Law 924; T Etherton 'Constructive trusts: A new model for equity and unjust enrichment' [2008] CLJ 265; S Gardner 'Family property today' (2008) 124 LQR 422.

${ }^{29}$ Stack [2007] UKHL 17 at [58] (Lady Hale).

${ }^{30}$ See A Briggs 'Co-ownership and an equitable non sequitur' (2012) 128 LQR 183; J Mee 'Ambulation, severance, and the common intention constructive trust' (2012) 128 LQR 500 for a discussion of the difficult questions of severance arising from the notion that a joint tenancy in equity is presumed from a joint tenancy at law.

${ }^{31}$ Stack [2007] UKHL 17 at [56] (Lady Hale).

32 Stack [2007] UKHL at [69] (Lady Hale). See, eg, M Dixon 'Casenotes editor's casenotes' [2007] Conveyancer \& Property Lawyer 352 for criticism.
} 
nature of the parties' relationship; whether they had children for whom they both had responsibility to provide a home...how the parties arranged their finances...[and] how they discharged the outgoings on the property and their other household expenses', need not necessarily be connected to financial contributions to the purchase of the home or discussions as to its acquisition. Moreover, there were also suggestions in Stack that the law had already 'moved on' since Lord Bridge's remarks in Rosset ${ }^{33}$ and that he 'set [the] hurdle rather too high, ${ }^{34}$ and it is significant that the allegedly strong presumption that equity follows the law was said to be displaced in Stack itself as well as in subsequent cases. ${ }^{35}$

In subsequent 'sole name' cases, English judges were largely reluctant to accept Stack's possible invitation to regard the law as having already 'moved on' since Rosset. In fact, while the judge in the first instance case of Hapeshi $v$ Allnatt cited the proposition that 'in response to changing social and economic conditions, the common intention [relevant to establishment of an interest] may be inferred (or perhaps imputed) from the parties' whole course of conduct in relation to the property ${ }^{, 36}$ an unfortunately restrictive approach was in evidence in other cases. In the Court of Appeal case of James $v$ Thomas, for example, a cohabitant engaged in unpaid manual work in her partner's business, thereby effectively

\footnotetext{
${ }^{33}$ Stack [2007] UKHL at [26] (Lord Walker).

${ }^{34}$ Stack [2007] UKHL at [63] (Lady Hale). See also Abbott v Abbott [2007] UKPC 53, [2008] 1 FLR 1451 at
} [3]-[6] (Lady Hale, giving the advice of the board).

${ }^{35}$ See, eg, Adekunle v Ritchie [2007] EW Misc 5 (EWCC), [2007] B.P.I.R. 1177 but cf. Fowler v Barron [2008] 2 FLR 831.

${ }^{36}$ [2010] EWHC 392 (Ch), [2010] WTLR 987 at [18] (Judge Hodge QC), citing C Harpum, S Bridge \& M Dixon Megarry \& Wade: The Law of Real Property (London: Sweet \& Maxwell, $7^{\text {th }}$ edn, 2008) at [11-025]. (The phrase 'it is now clear that' seems to have been inserted between 'economic conditions' and 'the common intention' in the equivalent paragraph of the $8^{\text {th }}$ edition (2012).) See M Dixon, 'Editor's notebook: The still not ended, never-ending story' [2012] Conveyancer \& Property Lawyer 83 at 84 on the weakness of the authority of Hapeshi on this point. 
contributing to the mortgage on the property owned by him. ${ }^{37}$ Sir John Chadwick decided that:

'...what [the claimant] was doing gives rise to no inference that the parties had agreed (or had reached a common understanding) that she was to have a share in the property: what she was doing was wholly explicable on other grounds' ${ }^{38}$

The defendant's remarks to the effect that improvements to the property would 'benefit us both' were held to relate to the couple's quality of life in the property rather than being 'intended or understood to be a promise of some property interest', ${ }^{39}$ which is a harsh conclusion even in the light of Rosset. Miss James was denied an interest in spite of $\mathrm{Mr}$ Thomas' candid concession that it would be 'fair' for her to have one, ${ }^{40}$ although a measure of justice was done in that she was held to be a partner in his business and it was understandable that the Court of Appeal was anxious to avoid imputation even though that is now permissible at the quantification stage following Jones.

In another post-Stack sole-owner case, Thomson v Humphrey, Warren $\mathrm{J}$ held that in relation to the establishment question 'it is necessary to go back to Lloyds Bank v Rosset', and that '[m]uch of what was said' in Stack related to the quantification question. ${ }^{42}$ In his distinctly cautious view, while '[a]ccepting that matters have moved on since Lord Bridge's

\footnotetext{
${ }^{37}$ [2007] EWCA Civ 1212.

${ }^{38}$ James [2007] EWCA Civ 1212 at [27].

${ }^{39}$ James [2007] EWCA Civ 1212 at [33]. It should also be noted that Ms James had conceded that Mr Thomas was 'evasive' and 'unwilling' when she raised the issue of putting the property into joint names (at [38]).

${ }^{40}$ James [2007] EWCA Civ 1212 at [37].

${ }^{41}$ [2009] EWHC 3576 (Ch) at [26].

${ }^{42}$ Thomson [2009] EWHC 3576 (Ch) at [25].
} 
restrictive requirement', it was 'not sensible to attempt to say what will and will not be enough'. ${ }^{43}$

Jones $v$ Kernott, by Lord Walker and Lady Hale's own admission, then gave the Supreme Court 'the opportunity to revisit the decision of the House of Lords in Stack $v$ Dowden' in late $2011 .^{44}$ In their joint lead judgment, they confirmed that 'the task of seeking to show that the parties intended their beneficial interests to be different from their legal interests was not to be "lightly embarked upon"[45], ${ }^{46}$ On the quantification point raised by the 'joint names' case, it was held that if the parties do seek to show that the legal and equitable interests differ either at the time of acquisition of the relevant property or later, ' $[t]$ heir common intention is to be deduced objectively from their conduct' ${ }^{47}$ It is necessary to ascertain 'the parties' common intentions as to what their shares in the property would be, in the light of their whole course of conduct in relation to it', with reference inter alia to the Stack paragraph 69 factors. ${ }^{48}$ Where there was clearly an intention that the interests would differ from the legal position, but 'it is not possible to ascertain by direct evidence or by inference what their actual intention was as to the shares in which they would own the property', each party is entitled to 'that share which the court considers fair having regard to

\footnotetext{
${ }^{43}$ Thomson [2009] EWHC 3576 (Ch) at [29].

${ }^{44}$ Jones [2011] UKSC 53 at [1].

${ }^{45}$ Stack v Dowden [2007] UKHL at [68] (Lady Hale).

${ }^{46}$ Jones [2011] UKSC 53 at [12] (Lord Walker and Lady Hale).

${ }^{47}$ Jones [2011] UKSC 53 at [52].

${ }^{48}$ Jones [2011] UKSC 53 at [13].
} 
the whole course of dealing between them in relation to the property, ${ }^{49}$ via the controversial process of imputation. $^{50}$

Our immediate concern, however, is the implications of Jones for sole-owner cases. Although Jones (like Stack) was a 'joint names' case, it confirmed that the presumption that equity follows the law applies whether legal title is held by one party or by more than one. Lord Walker and Lady Hale held that '[a]t a high level of generality', there is 'a single regime' governing sole and joint name cases, and they recognised that 'a "common intention" trust is of central importance to "joint names" as well as "single names" cases'. ${ }^{1}$ Logically, however, in a 'sole name' case '[t]he starting point is different because the claimant whose name is not on the proprietorship register has the burden of establishing some sort of implied trust, normally...a "common intention" constructive trust'. ${ }^{52}$ In their analysis Lord Walker and Lady Hale made the traditional distinction between the 'first issue', a prior one, of 'whether it was intended that the other party have any beneficial interest in the property at all', and the 'second issue' of 'what that interest is'. ${ }^{53}$ In relation to the latter issue, it was held that the quantification process should proceed in a sole owner case as outlined above in relation to joint owner cases.

Significantly, however, Lord Walker and Lady Hale suggested that even in relation to the 'first issue' in a 'sole name' case, the common intention of the parties 'has once again to

\footnotetext{
${ }^{49}$ Jones [2011] UKSC 53 at [51] (Lord Walker and Lady Hale), citing Chadwick LJ in Oxley v Hiscock [2004] EWCA Civ 546 at [69].

${ }^{50}$ Lord Kerr emphasised that imputation 'has nothing to do with what the parties intended, or what might be supposed would have been their intention had they addressed that question': Jones [2011] UKSC 53 at [74].

${ }^{51}$ Jones [2011] UKSC 53 at [16].

${ }^{52}$ Jones [2011] UKSC 53 at [17].

${ }^{53}$ Jones [2011] UKSC 53 at [52].
} 
be deduced objectively from their conduct', ${ }^{54}$ reflecting the terminology employed by Lord Diplock in Gissing v Gissing. ${ }^{55}$ This looks like a significant departure from Rosset, potentially implying that at least some of the Stack paragraph 69 factors are relevant to the establishment as well as the quantification of interests, but unfortunately the matter is not clear cut and there are interpretative arguments to be made on either side.

On the one hand, admittedly Lord Walker and Lady Hale did not either repeat or refer to their earlier suggestions in Stack that Rosset no longer governed the establishment issue, and there is a possibility that the phrase 'once again' related to the ascertainment of the common intention on the quantification of interests rather than their establishment in a 'sole name' case since the next stage in the analysis is said to be imputation. The two Justices avoided explicitly disapplying Lord Bridge's restrictions as forming part of the method by which the relevant objective deduction on establishment should be performed and, by analogy with the detrimental reliance requirement, ${ }^{56}$ it could be argued that those Rosset restrictions were so fundamental to the general understanding of this area of the law that a mere omission to cite them in Jones (or in any other relevant case) should not be thought significant. Lord Walker and Lady Hale's remarks were clearly obiter as regards sole owner cases, and the reinforced strength of the presumption that equity follows the law suggests that the legal nonowner still carries a heavy burden even if he is not restricted to the Rosset criteria. Moreover, Lord Collins explicitly mentioned sole owner cases only to point out that the cases pre-dating Stack involved different facts, ${ }^{57}$ and Lord Kerr did not appear to mention them at all.

\footnotetext{
${ }^{54}$ Jones [2011] UKSC 53 at [52].

${ }^{55}$ Gissing [1971] AC 886 HL at 907.

${ }^{56}$ See the text to $\mathrm{n} \mathbf{1 8}$ above.

57 Jones [2011] UKSC 53 at [59].
} 
Nevertheless, on the other side of the argument, it remains true that Lord Walker and Lady Hale did not expressly limit the conduct by reference to which the common intention could be inferred to the types stipulated in Rosset. Indeed, they did not cite Rosset at all, and the only citation of that earlier case came from Lord Collins when discussing the differences between inference and imputation. ${ }^{58}$ This failure to cite Rosset on the question of establishing an interest coupled with the earlier criticism of it in Stack and the implication that it had stopped representing the law before Stack was decided suggests that it should no longer be followed. Even if there are difficulties with relying on a mere omission to cite it in Jones, the analogy with the omission of the detrimental reliance requirement is not exact since, unlike Rosset, detrimental reliance was not mentioned in Stack either. In addition, the deliberate repetition of the language of objective deduction from conduct implies that the factors from paragraph 69 of Stack are relevant to establishing an interest as well as quantifying it, ${ }^{59}$ and that establishing an interest in a 'sole name' cases is equivalent to demonstrating that legal and equitable interests should differ in a 'joint names' case, ${ }^{60}$ although it is true that the Justices did not expressly refer back to their earlier use of that language in spite of the fact that they were prepared to make similar cross-references on the approach to quantification. ${ }^{61}$ As regards the obiter status of their remarks, it is clear that Lord Walker and Lady Hale set out to provide a coherent framework for both sole and joint owner cases, even if the former were not directly relevant on the facts, and Lady Hale expressed the view in Stack that Lord

\footnotetext{
${ }^{58}$ Jones [2011] UKSC 53 at [59].

59 Jones [2011] UKSC 53 at [51]-[52].

${ }^{60}$ See also Jones [2011] UKSC 53 at [82] (Lord Wilson), and Pawlowski's view that 'the essential inquiry boils down to the same thing' in both sole and joint owner cases: M Pawlowski 'Imputed intention and joint ownership - a return to common sense: Jones v Kernott' [2012] Conveyancer \& Property Lawyer 149 at 158.

${ }^{61}$ Jones [2011] UKSC 53 at [52], referring to paras [51](4) and [51](5).
} 
Bridge's restrictions in Rosset were themselves obiter, ${ }^{62}$ presumably because the criteria did not need to be set so onerously in order to decide the case. Finally, while Lord Wilson opined that the question whether imputation was permitted in establishing that the legal and equitable interest differed (rather than the quantification of the equitable interest) would 'merit careful thought' in an appropriate case, he did not place any limitations upon the methods by which such an intention could be inferred. ${ }^{63}$

Given the policy objections to Rosset and the fact that the upper echelons of the judiciary have (perhaps deliberately) created uncertainty as to the extent to which it still applies, it would be normatively desirable for the lower courts to move beyond Rosset if necessary in a given case even if they are reined in by a subsequent Supreme Court decision. That would force the Supreme Court to confront the issue head-on, which would be of general benefit to the law and parties to future disputes even if it would be costly for one set of litigants. The system of precedent may cause difficulties for the lower courts in taking a bold approach, ${ }^{64}$ but it is worth noting that Lord Reid as far back as Gissing v Gissing saw "no good reason' for the distinction between direct and indirect financial contributions, opining that 'in many cases it would be unworkable', ${ }^{65}$ and that Lord Walker used the past tense when asserting in Stack that the law had moved on. ${ }^{66}$

${ }^{62}$ Stack [2007] UKHL 17 at [63]. See also K Lees 'Geary v Rankine: Money isn't everything' [2012] Conveyancer \& Property Lawyer 412 at 418.

${ }^{63}$ Jones [2011] UKSC 53 at [84].

${ }^{64}$ J Lee 'The Supreme Court and the Doctrine of Precedent' (Inner Temple Academic Fellow's Lecture, originally given 23 April 2011)

$<$ http://www.innertemple.org.uk/downloads/education/lectures/lecture_james_lee.pdf $>$ at 11-16 highlights similar precedential difficulties with the permission of imputation in Jones.

${ }^{65}$ [1971] AC 886 HL at 896. See also Lords Pearson (at 903) and Diplock (at 907-8) on the relevance of indirect financial contributions where they facilitated mortgage payments by the legal owner. The remarks of Lords Reid 
Problems of uncertainty might well abound if a more holistic approach were taken to the acquisition question, and the answer to the fundamental question whether a legal nonowner does or does not have an interest in a given piece of property could become extremely difficult to predict before litigation. It might also be questioned whether the Stack factors that go beyond Rosset are appropriate in cases that are 'domestic' in character but do not simply involve couple-based familial relationships. ${ }^{67}$ But such difficulties already arise on the quantification question and the Stack/Jones approach does at least attempt to consider the full range of matters that might be relevant to a common intention between parties to a domestic relationship of whatever sort. Indeed, the whole rationale of the majority approach in Stack was a recognition that a narrow focus on matters such as direct financial contributions was inadequate as a means of ascertaining common intention in this context. Even a willingness to consider indirect financial contributions would liberalise the law while a refusal to consider wholly domestic contributions or to allow common intention to be imputed on the establishment question, for example, would place a pragmatic limitation on development and prevent a wholesale abandonment of the Rosset framework. Moreover, it is difficult to find a normative justification for treating the 'establishment' and 'quantification' questions so differently when the essential question is ostensibly about the common intention of the parties

and Diplock were used by Lord Walker in Stack to support his doubts about Lord Bridge's approach: [2007] UKHL at [26].

${ }^{66}$ See Law Commission, Cohabitation: The Financial Consequences of Relationship Breakdown - A Consultation Paper (Law Com No 198, London: HMSO, 2006) at [3.30] for discussion of pre-Stack judicial remarks about the permissible bases of inference.

${ }^{67}$ See, eg, Rezaeipoor v Arabhalvai [2012] EWHC 146 (Ch); Gallarotti v Sebastianelli [2012] EWCA Civ 865, [2012] 2 FLR 1231. Cf. B Sloan Informal Carers and Private Law (Oxford: Hart Publishing 2013) pp 81-88 for a discussion of the application of the common intention constructive trust in cases involving non-conjugal 'carer' relationships. 
in both cases, though a rather more cautious view is taken by Yip. ${ }^{68}$ It is also the case that the very question considered in this article is itself a considerable cause of uncertainty in the law.

Whatever the correct view of the implications of Jones as regards establishment of interests, and wary of the difficulties in resolving the perpetual normative debate on whether the constructive trust should develop to accommodate more legal non-owners, the main part of this article explores whether the judiciary have in fact taken the apparent opportunity to liberalise the restrictive Rosset approach following Jones.

\section{JUDICIAL REACTIONS TO JONES}

The many domestic common intention constructive trust cases ${ }^{69}$ decided since Jones may plausibly but broadly be divided into three categories: those where the possible impact of

\footnotetext{
${ }^{68}$ M Yip, 'The Rules Applying to Unmarried Cohabitants' Family Home: Jones v Kernott' [2012] Conveyancer \& Property Lawyer 159 at 162-63.

${ }^{69}$ In addition to the cases discussed in detail in this article, the 'joint names' domestic case of Quaintance $v$ Tandan (unreported, Chancery Division, 24 July 2012) will have raised some relevant issues, although in the absence of a transcript (at the time of writing) it would be unwise to comment further. The judgment in $W v M$ (TOLATA Proceedings: Anonymity) [2012] EWHC 1679 (Fam), [2013] 1 FLR 1513 essentially concerned anonymity. In the 'sole name' domestic case of Curran v Collins [2013] EWCA Civ 382, the trial judge appears to have adopted a restrictive approach. In granting permission to appeal to the Court of Appeal (largely relating to a separate point), Toulson LJ branded the law of trusts 'potentially unfair to people in the appellant's position', but considered that 'the judge was constrained to apply the law as it is' (at [9]). In Crossco No 4 Unlimited v Jolan Ltd [2011] EWCA Civ 1619, the claimants asserted that by virtue of certain oral discussions, the defendants were prevented from operating a break clause in a commercial lease. In the Court of Appeal (cf. [2011] EWHC 803 (Ch), [2011] NPC 38), they based their (unsuccessful) submissions around constructive trusts and estoppel. The common intention variety of constructive trust developed in cases such as Jones was not held to apply in a commercial case such as the one at hand. On Etherton LJ's view it was also distinct from the
} 
Jones in moving beyond Rosset was (in some instances rather shamefully) ignored; those 'sole name' cases where the influence of Jones was recognised but the outcome (in terms of establishing rather than quantifying the relevant beneficial interest) would have been permissible following Rosset; and those where Jones appears to have produced a novel result in a 'sole name' case. These categories structure the analysis for the remainder of the article, although sub-categories are also used. Most of the significant cases, and notably the Court of Appeal authorities, appear to fall in the middle category. Nevertheless, it will be seen that a

Pallant v Morgan equity (see, originally, [1953] Ch 43) on which the claimants also relied, although McFarlane LJ and Arden LJ differed from him in that respect (see also Kearns Brothers Ltd v Hova Developments Ltd [2012] EWHC $2968(\mathrm{Ch}))$. It seems that Jones was intended to be cited in $K K v M A$ [2012] EWHC 788 (Fam) at [19] (Charles J), but the transcript briefly and probably mistakenly refers to Jones $v$ Kaney [2011] UKSC 13, [2011] 2 AC 398. Chapman v Jaume [2012] EWCA Civ 476, [2012] 2 FLR 830 involved expenditure by the claimant on the home registered in his cohabitant's 'sole name', but Lewison LJ opined that the case was about neither resulting nor constructive trusts but the claimant's case 'that he is simply entitled to have his money back' (at [19]). In Shirt v Shirt [2012] EWCA Civ 1029, [2012] 3 FCR 304, the law on constructive trusts was not analysed in sufficient depth even to distinguish it from that on proprietary estoppel, and Slater $v$ Condappa [2012] EWCA Civ 1506 was in substance analysed (without reference to authority) as an estoppel case turning on the evidence. Favor Easy Management Ltd v Wu [2012] EWCA Civ 1464 (cf. M Yip and J Lee "“Less than straightforward" people, facts and trusts: reflections on context: Favor Easy Management Ltd v Wu' [2013] Conveyancer and Property Lawyer 431), Shami v Shami [2013] EWCA Civ 227, Mukerjee v Sen [2013] EWHC 1997 (Ch) and $M v M$ [2013] EWHC 2534 (Fam) raised some relevant issues but the judgments contain no indepth discussion of the relevant law. In Pankhania v Chandegra [2012] EWCA Civ 1438, [2013] 1 P \& CR 16), the Court of Appeal held that there was in fact an express declaration of trust in relation to the relevant property so that reliance on Jones was misplaced. Finally, the appeal in the 'joint names' case of Akhtar v Hussain [2012] EWCA Civ 1762 was ultimately confined to the issue of occupation rent (see [2012] EWCA Civ 1170 for the judgment on permission to appeal). 
conclusion arguably inconsistent with Rosset was reached in the successful High Court claim in Aspden $v$ Elvy ${ }^{70}$ which might have ramifications for the future.

\section{(a) Jones Ignored or Fully Distinguished?}

This section considers cases where Jones was not applied at all. Such cases, all of them first instance authorities that did not involve genuine contests between alleged co-owners but had real significance for third parties, can be sub-categorised into those where Jones was not cited or considered at all, and those where it was considered but not expressly applied to the facts and the Rosset approach was preferred.

\section{(i) JONES COMPLETELY IGNORED}

One case where Jones seems to have been ignored altogether is Garwood v Ambrose. ${ }^{71}$ This is in spite of the fact that it was a 'joint names' case to which Jones should have been directly applicable. $\mathrm{Mr}$ and Mrs Ambrose were the registered proprietors of their home. The husband's trustee in bankruptcy sought declarations inter alia that the husband's beneficial interested in the property had not been vested in the wife by virtue of an express or implied trust.

The purported declaration of trust had been made in 2008 using a 'short, but rather unusual' document stating that 'Mr and Mrs Ambrose hold the property as tenants in common in unequal shares'. ${ }^{72}$ It also declared, however, that as from $18^{\text {th }}$ July the previous year the

\footnotetext{
${ }^{70}$ [2012] EWHC 1387 (Ch), [2012] 2 FLR 807.

${ }^{71}$ [2012] EWHC 1494 (Ch), [2012] BPIR 996.

${ }^{72}$ Garwood [2012] EWHC 1494 (Ch) at [17] (Judge Leaver QC).
} 
wife was 'beneficially entitled to the whole of the remaining net equity in the property' ${ }^{73}$ While Judge Leaver QC accepted that Mr and Mrs Ambrose understood that the wife was now the sole beneficial owner because the husband's equity had been exhausted in discharging previous debts, he held that 'there was no agreement to that effect and no declaration of trust' in July 2007 evidenced by the later deed, ${ }^{74}$ and that the purported declaration of trust in 2008 would (if valid) have been a transaction at an undervalue falling foul of the Insolvency Act $1986 .^{75}$

The judge then turned to the 'implied' (by which he meant constructive) trust issue, ${ }^{76}$ and in doing so applied (and indeed mentioned) only Rosset. In spite of the attempt to declare a trust in her favour and the earlier finding that the parties understood the wife to be the sole beneficial owner, the judge held there was no constructive trust because there were none of the express discussions required by Lord Bridge in order to demonstrate an express common intention. Although they may not have been important on the facts, ${ }^{77}$ the judge did not explicitly address the possibility of even direct financial contributions sufficing as evidence of common intention per se following Rosset, focusing on a supposed absence of detrimental reliance because Mrs Ambrose had taken on no additional responsibility for the mortgage after July 2007 notwithstanding the doubts expressed about the necessity for such reliance following Stack and Jones.

\footnotetext{
${ }^{73}$ Garwood [2012] EWHC 1494 (Ch) at [17].

${ }^{74}$ Garwood [2012] EWHC 1494 (Ch) at [19].

${ }^{75}$ Garwood [2012] EWHC $1494(\mathrm{Ch})$ at [22]. Any interest by the wife as a direct result of the declaration of trust was therefore the subject of an order under the Insolvency Act 1986, s 339 vesting that interest in the husband's trustee in bankruptcy as part of the husband's estate.

${ }^{76}$ Garwood [2012] EWHC 1494 (Ch) at [23].

${ }^{77}$ See, eg, Garwood [2012] EWHC 1494 (Ch) at [20] (Judge Leaver QC).
} 
The fact that the wife was asserting an express or constructive trust over what would otherwise have been her husband's interest while it was seemingly accepted that she already held at least a 50\% interest rendered the admittedly complex Garwood case similar to a 'sole name' scenario. Nevertheless, it was self-evidently not a 'sole name' scenario in a technical sense, and it is odd to say the very least that Judge Leaver QC failed expressly to follow the approach set out in Jones $v$ Kernott to be applied in 'joint names' cases. Even from the perspective of genuine legal non-owners, it is worrying that Rosset can still be seen as the sole applicable or even relevant authority (and even then be applied in an incomplete manner) notwithstanding developments in the ensuing two decades or more culminating in Jones. Garwood's status as a High Court decision cements its weakness as an authority.

Jones was not cited in Rezaeipoor v Arabhalvai either. ${ }^{78}$ There, the claimant creditor had a charging order in respect of a debtor's interest (if any) in a flat owned at law by the debtor's sister. Master Bragge had decided (several months before the Supreme Court gave judgment in Jones) that the debtor had no interest in the flat since following Stack the burden of proof was on the claimant to establish one. He also held that the creditor 'had to establish on the balance of probabilities that there was an agreement, arrangement or understanding between the brother and sister that the sister was a nominee, or that the funds for the purchase came from the brother', and had failed to do so. ${ }^{79}$ Deputy Judge Kevin Prosser QC held (in February 2012) that the Master had 'correctly' approached the law on beneficial ownership. ${ }^{80}$ The deputy judge omitted to distinguish between resulting and constructive trusts, ${ }^{81}$ and made no comment on the fact the Master's formulation more obviously reflected Rosset rather than

\footnotetext{
${ }^{78}$ [2012] EWHC 146 (Ch).

${ }^{79}$ Rezaeipoor [2012] EWHC $146(\mathrm{Ch})$ at [15].

${ }^{80}$ Rezaeipoor [2012] EWHC $146(\mathrm{Ch})$ at [15].

${ }^{81}$ See the text to $\mathrm{n} \mathbf{1 6}$ above.
} 
Jones if the case was being analysed as one suiting a constructive trust analysis. It is at least heartening that Rosset was fully applied in substance in that case.

\section{(ii) JONES CONSIDERED BUT NOT APPLIED TO THE ACQUISITION QUESTION}

There have been other cases where, less dramatically than those considered above, Jones has been cited but not applied. Re Ali concerned five properties whose legal title was held solely or jointly by a convicted money launderer, Mr Ali. ${ }^{82}$ Confiscation and restraint orders had been made against him, but various members of his family sought to establish, or increase the quantum of, a beneficial interest in the properties. Unlike Garwood and Rezaeipoor, Jones was cited (along with Stack) in Dobbs J's judgment. However, she held that in considering whether a legal non-owner had any interest in the relevant property at all 'there will need to be evidence of an actual agreement, arrangement or understanding between the parties'. ${ }^{83}$ She cited Rosset in support of that proposition, and considered that only in relation to the quantification question could the court have regard to the "whole course of dealing" between the parties, in order to ascertain their intentions, or, if necessary, to impute them'. ${ }^{84}$ Surprisingly, and bringing her analysis closer to that in Garwood, Dobbs J appeared to think financial contributions relevant only to the establishment of a resulting, rather than a constructive, trust. ${ }^{85}$ She also held that 'the carrying out of work on the property of another without more (in other words mere conduct), does not provide the party carrying out the work with a beneficial interest save in exceptional circumstances'. ${ }^{86}$ The judge went on to dismiss

\footnotetext{
${ }^{82}$ [2012] EWHC 2302 (Admin).

${ }^{83}$ Re Ali [2012] EWHC 2302 (Admin) at [104].

${ }^{84}$ Re Ali [2012] EWHC 2302 (Admin) at [105].

${ }^{85}$ Re Ali [2012] EWHC 2302 (Admin) at [108].

${ }^{86}$ Re Ali [2012] EWHC 2302 (Admin) at [106].
} 
all claims to a beneficial interests by the legal non-owners on the facts, while opining that even if 'one were to stand back and take the holistic approach' of Jones to the establishment question, 'there are still difficulties with the applicants' case', ${ }^{87}$ particularly since much of the evidence of common intention related to the period after the confiscation and restraint orders were made.

A similarly restrictive (and, with respect, incorrect) reading even of Rosset was taken in Ullah $v$ Ullah, in which the claimant (who had been adjudged bankrupt) sought to establish an interest in properties held at law by one or both of his sons. ${ }^{88}$ While Deputy Judge John Martin QC accepted that a common intention could be express or inferred from conduct, citing Jones $v$ Kernott, he also considered Lord Bridge's remarks about express discussions and did not even cite the remarks in Rosset about direct financial contributions being relevant to a common intention constructive trust. ${ }^{89}$ Indeed, the deputy judge held that if the claimant 'cannot establish a common intention constructive trust', ${ }^{90}$ he 'would in principle be able to establish a resulting trust if he could show that he had made direct contributions to the purchase price' ${ }^{91}$ In rejecting the claims (albeit in the case of two properties because of the bankruptcy and a subsequent assignment), the deputy judge therefore focused on discussions and financial contributions.

Another case that invites pessimism for legal non-owners who would benefit from a broader approach, albeit with more impressive legal analysis, is Serious Organised Crime Agency $v$ Coghlan. ${ }^{92}$ In it, the Agency ('SOCA') successfully claimed that a property was

\footnotetext{
${ }^{87}$ Re Ali [2012] EWHC 2302 (Admin) at [148].

${ }^{88}$ [2013] EWHC 2296 (Ch).

${ }^{89}$ Ullah [2013] EWHC 2296 (Ch) at [6].

${ }^{90}$ Ullah [2013] EWHC 2296 (Ch) at [6] (emphasis added).

${ }^{91}$ Ullah [2013] EWHC 2296 (Ch) at [6].

${ }^{92}$ [2012] EWHC 429 (QB), [2012] Lloyd's Rep FC 341.
} 
recoverable and that the defendant suspected drug dealer Mr Coghlan had acquired the beneficial title to it before obtaining the legal title in 2007. An aspect of the defence was that Mr Coghlan's cohabiting partner, Ms Burgoyne, had innocently acquired an interest in the property by virtue of Jones $v$ Kernott from the moment Mr Coghlan had acquired the legal title, and before it was transferred into her and Mr Coghlan's joint names in 2009. The 2009 transfer was considered by Simon J to be 'no more than the latest step in Mr Coghlan's attempts to place his property beyond the reach of SOCA, ${ }^{93}$ and was not made for value such that Ms Burgoyne's supposed interest was still recoverable under the relevant legislation. ${ }^{94}$ The judge's conclusion carries with it an acceptance of SOCA's submission that there was no constructive trust in Ms Burgoyne's favour before the transfer. The submission was justified on the basis that there was no 'common intention with some action to her detriment' and her contributions to the interest-only mortgage 'constituted no greater contribution than the payment of an electricity bill'. ${ }^{95}$ While Jones was at least cited in his judgment, Simon J's analysis does not reflect a realisation of Jones' possible implications in 'sole name' cases as compared to Rosset, but the issue was not considered at length.

It can therefore be seen that the approach of the Supreme Court in Jones has not yet reached all judicial corners, although the decision not to apply it has not been taken with enormous care in any of the cases considered in this section, even where it has been cited. It is significant that they are all High Court authorities, and also that they occurred in the context of debt or crime and were not all genuine contests between putative co-owners. While some such cases could be characterised as 'investment' situations better suited to a resulting trust

\footnotetext{
${ }^{93}$ Coghlan [2012] EWHC 429 (QB) at [16].

${ }^{94}$ Proceeds of Crime Act 2002, s 308.

${ }^{95}$ Coghlan [2012] EWHC 429 (QB) at [112].
} 
approach, ${ }^{96}$ others can remain 'domestic' as between the legal owner and the person trying to establish or increase an interest in the relevant property in spite of their 'non-domestic' wider context. $^{97}$

That said, the interests of third parties and the associated policy factors might in practice assume particular importance in some cases of this sort. For example, in some such cases there could be an increased chance of suspicion that the common intention constructive trust is being invoked by some form of 'wrongdoer' to defeat the legitimate claims of creditors or even the state, and it is probably fair to say that the judges deciding them are both under considerable time pressure and less likely to be accustomed to applying the intricacies of the law on common intention constructive trusts than some of their colleagues. This can be inferred from the fact that even Rosset does not appear to have been fully understood and applied in all of the cases considered in this section. Such misunderstandings and uncertainties, while not perhaps surprising, do little for the coherence of the law. This is particularly true since there are cases with similar facts and contexts (analysed in the next section of this article) where Jones was considered relevant, and there are also insufficient factual differences to explain the discrepancy between cases where Jones was ignored altogether and those where it was considered but deliberately not applied.

\section{(b) Liberal Principles, Orthodox Results}

In spite of the pessimism about the reach of Jones expressed in the previous section, there have been a number of 'sole name' cases and others in which judges have incorporated its principles into their analysis of the current law notwithstanding their partially obiter status. This is true in

\footnotetext{
${ }^{96}$ See, eg, Laskar v Laskar [2008] EWCA Civ 347.

${ }^{97}$ See, eg, the remarks of Holman J cited in $\mathrm{n} \mathbf{1 1 1}$ below.
} 
spite of the fact that Jones has not (subject to the possible exception considered in the next section) had a conspicuous influence on the outcome of the cases as compared to Rosset. The section begins by setting out the legal analyses undertaken that include Jones in 'sole name' cases, and then considers the cases grouped by level of court and then by outcome.

\section{(i) LEGAL ANALYSES}

The Court of Appeal has made significant use of the Jones principles since that case was decided. It had an opportunity to consider the impact of Jones in the sole-owner case of Geary $v$ Rankine ${ }^{98}$ which involved a constructive trust claim by Mrs Geary in respect of a guest house purchased and owned at law by her former cohabitant. ${ }^{99}$ Lewison LJ (with whom Etherton and Thorpe LJJ simply agreed) began his analysis of the constructive trust issue by stating that Mrs Geary bore the burden of proving that she had any interest at all. In his view, '[t]he burden is all the more difficult to discharge where, as here, the property was', at least initially, 'bought as an investment rather than as a home' ${ }^{100}$ In spite of this, Lewison LJ clearly stated that even in a 'sole name' case '[t]he search is to ascertain the parties' actual shared

\footnotetext{
98 [2012] EWCA Civ 555, [2012] 2 FLR 1409.

${ }^{99}$ She also claimed that she was a partner in the business, and much of her unsuccessful appeal focused on that aspect of the case.

${ }^{100}$ Geary [2012] EWCA Civ 555 at [18]. Lewison LJ considered the possibility that the resulting trust applied in this case, though clearly he did not think the case to be so investment-focused that the Stack/Jones analysis was utterly inappropriate. Cf., eg, Laskar v Laskar [2008] EWCA Civ 347, discussed along with matters of 'context' in property law in N Piska, 'Two recent reflections on the resulting trust' [2008] Conveyancer \& Property Lawyer 441; B Sloan 'Proprietary Estoppel: Recent developments in England and Wales' (2010) 22 Singapore Academy of Law Journal 110.
} 
intentions, whether express or to be inferred from their conduct'. ${ }^{101}$ While he was careful to confine the possibility of imputation to cases where an actual intention to share had been established and the only uncertainty is as to the size of the interest, this is a significant statement at an appellate level since it reflects an appreciation that Lord Walker and Lady Hale's judgment in Jones is relevant to a sole-owner case. Lewison LJ's analysis of the law, on Lees' view, 'ought to put to bed any remaining notions that the restrictions of Rosset still apply to the question of acquisition'. ${ }^{102}$ However, Lees may well exaggerate the position on the basis of a mere omission to cite the restrictions in a case where they would in principle have been applicable. The same could be said of Thompson v Hurst, where Etherton LJ similarly asserted that in a 'sole name' case such as the one at hand the establishment of an interest still depended on 'evidence of the parties' actual intentions, express or inferred, objectively ascertained ${ }^{103}$ and did not mention the Rosset restrictions.

In Gallarotti v Sebastianelli, ${ }^{104}$ which involved a dispute not between a conjugal couple but between two 'single people' who decided to acquire a flat to share, ${ }^{105}$ Arden LJ (with whom Tomlinson and Davis LJJ simply agreed) nevertheless emphasised that the Court of Appeal was not being asked to 'decide any new question of substantive law' and boldly opted not to refer to a single authority in her judgment. ${ }^{106}$ Indeed, she went so far as to criticise the Recorder's first instance judgment because it 'set out in detail the recent authorities on common intention

\footnotetext{
${ }^{101}$ Geary [2012] EWCA Civ 555 at [18]. See also [19], [20].

${ }^{102}$ K Lees ‘Geary v Rankine: Money Isn't Everything’ [2012] Conveyancer \& Property Lawyer 412 at 418.

${ }^{103}$ [2012] EWCA Civ 1752, [2013] 1 FCR 522 at [19]. See also Crossco No 4 Unlimited v Jolan Ltd [2011] EWCA Civ 1619 at [85] (Etherton LJ).

${ }^{104}$ [2012] EWCA Civ 865.

${ }^{105}$ Gallarotti [2012] EWCA Civ 865 at [1].

${ }^{106}$ Gallarotti [2012] EWCA Civ 865 at [2].
} 
constructive trust' in spite of the common ground between the parties. ${ }^{107}$ She nevertheless proceeded to examine 'the conduct of the parties throughout their relationship', ${ }^{108}$ which suggests that she had Stack and/or Jones vaguely in mind. That said, she also agreed with the Recorder's questionable assertion that while this was a domestic case, 'the principles to be applied to a constructive trust were the same whether the parties were in a relationship such as that of husband and wife or were business associates, though the court might draw different inferences as to their conduct in the latter case'. ${ }^{109}$ Gallarotti is not, therefore, a particularly useful authority.

Smith $v$ Bottomley is another problematic Court of Appeal judgment in terms of its legal analysis, partly because the Court did not engage in any substantive analysis of the common intention question and simply relied on that of Judge Shaun Spencer QC at first instance. For his part, the judge below had held that 'Ms Smith's claim...depended completely on the express promise made to her by Mr Bottomley', citing Lloyds Bank v Rosset, and that on the facts 'no inference could be drawn from the parties' conduct of any wider common intention to share property'. ${ }^{110}$ The very fact that a 'wider common intention' was in principle considered relevant nevertheless suggests a Jones-inspired approach. Moreover, the claimant appears to have placed specific emphasis on 'promises' in her pleadings, and the case ultimately turned on problems with the parties to a relevant common intention, the timing of promises and detrimental reliance rather than the existence of a common intention between the two cohabitants. In any event, the Court of Appeal could certainly be criticised for failing to provide clarity on the common intention point.

\footnotetext{
${ }^{107}$ Gallarotti [2012] EWCA Civ 865 at [31].

${ }^{108}$ Gallarotti [2012] EWCA Civ 865 at [5].

${ }^{109}$ Gallarotti [2012] EWCA Civ 865 at [6]. Cf., eg, Stack v Dowden [2007] UKHL 17 at [69] (Lady Hale) and [3] (Lord Hope); Laskar v Laskar [2008] EWCA Civ 347.

${ }^{110}$ [2013] EWCA Civ 953 at [19] (Sales J).
} 
As well as being influential for the most part in the Court of Appeal when it has engaged in legal analysis, and in spite of the cases considered in the last section of this article, Jones has also had a significant impact on the apparent understanding of the law in the lower courts even in the context of debt or crime. In Crown Prosecution Service $v$ Piper, a husband and wife both sought to demonstrate that the wife had a beneficial interest in their home notwithstanding her lack of a legal interest, in order to prevent the house being sold to satisfy a criminal confiscation order made against the husband. ${ }^{111}$ In setting out the relevant legal framework agreed by counsel, in contrast to several of the crime and debt cases considered in the previous section of this article, Holman $\mathrm{J}$ repeated the Jones formulation that the common intention of the parties 'is to be deduced objectively from their conduct', ${ }^{112}$ and cited ${ }^{113}$ Lord Diplock's assertion in Gissing $v$ Gissing that '[ $\mathrm{t}]$ he relevant intention of each party is the intention which was reasonably understood by the other party to be manifested by that party's words and conduct notwithstanding that he did not consciously formulate that intention in his own mind'. ${ }^{114}$ While Holman $\mathrm{J}$ was clear that 'if the wife has made some financial contribution referable to the transfer of [the property] to the husband, it can readily be inferred that it was intended that the wife should have a beneficial interest in that property', ${ }^{115}$ the judge also concurred in the view that paragraph 69 of Stack was 'illuminating' as regards

\footnotetext{
${ }^{111}$ [2011] EWHC 3570 (Admin). Due to the co-operation between Graham and Janet Piper, Holman J was conscious of the need to scrutinise their evidence carefully, but was also clear that when adjudicating upon the existence and extent of Janet's interest, '[t]he answer is the same whether the husband and wife are pitted against each other in bitter conflict, or are ranged together in opposition to the CPS' (at [6]).

${ }^{112}$ Piper [2011] EWHC 3570 (Admin) at [10].

${ }^{113}$ Piper [2011] EWHC 3570 (Admin) at [10].

${ }^{114}$ [1971] AC $886 \mathrm{HL}$ at 906.

${ }^{115}$ Piper [2011] EWHC 3570 (Admin) at [11].
} 
establishing, and not merely quantifying, a beneficial interest. ${ }^{116}$ In Rubin v Dweck, it was similarly held that the presumption that a sole legal owner was also the sole beneficial owner could be rebutted by a common intention that could 'arise from express agreement or be inferred either by contribution to the purchase price or from the parties' whole course of conduct in relation to the Property'. ${ }^{117}$ This clearly moves beyond Rosset, albeit that $\mathrm{Mr}$ Registrar Jones cited Stack rather than Jones as the relevant authority and the decision is one of the bankruptcy court in the chancery division. On the other hand, while Holman J cited in $C P S \vee$ Piper the proposition that the law had moved on from the view of Lord Bridge in Rosset, he rather strangely did so when outlining the process of quantification rather than that of establishing the interest. ${ }^{118}$

In Aspden v Elvy, ${ }^{119}$ Judge Behrens based his exposition of the law on an extra-judicial lecture given by Judge Bridge. ${ }^{120}$ In ascertaining the correct approach to be taken in a soleowner case such as the one at hand, Judge Behrens focused largely on Jones and Stack and noted Lord Walker's remark in Stack about the law having moved on since Rosset. ${ }^{121}$ In the Northern Irish sole-owner case of Bank of Scotland v Brogan, ${ }^{122}$ meanwhile, Deeny J began his analysis with Jones and Stack, and did not cite Rosset at all. Similarly, in Patel v Vigh, Judge Halpern QC did not cite Rosset and was content to adopt 'as a working formulation'

\footnotetext{
${ }^{116}$ Piper [2011] EWHC 3570 (Admin) at [10].

${ }^{117}$ [2012] BPIR $854(\mathrm{Ch})$ at [13] (Mr Registrar Jones).

${ }^{118}$ Piper [2011] EWHC 3570 (Admin) at [6].

${ }^{119}$ [2012] EWHC 1387 (Ch), [2012] 2 FLR 807.

${ }^{120}$ Aspden [2012] EWHC 1387 (Ch) at [91] fn 1.

${ }^{121}$ Aspden [2012] EWHC 1387 (Ch) at [95].

${ }^{122}$ [2012] NICh 21.
} 
counsel's agreed summary of the law, which was 'drawn largely' from paragraph 51 of Lord Walker and Lady Hale's judgment in Jones $v$ Kernott. ${ }^{123}$

There is therefore a solid recognition amongst a significant portion of the judiciary that Stack and Jones are now the leading authorities even in 'sole name' cases. However, it is not clear that the result in the majority of these cases, in terms of establishing rather than quantifying the interest of the legal non-owner, would have been any different had Rosset been applied. At the same time, it is equally unclear that any failure to establish a beneficial interest in such cases has been caused by a reluctance to apply Jones in preference to Rosset. These matters are considered in the following sub-sections.

\section{(ii) SUCCESSFUL COURT OF APPEAL CLAIMS}

The successful claim to a beneficial interest in Gallarotti $v$ Sebastianelli involved a flat vested in Mr Sebastianelli's 'sole name'. ${ }^{124}$ The parties had an agreement (not amounting to an express trust) to the effect that they would have equal shares in the flat, but also agreed that the claimant Mr Gallarotti would increase his payments towards $\mathrm{Mr}$ Sebastianelli's mortgage to counterbalance the former's lower contribution towards the purchase price. ${ }^{125}$ Ultimately,

\footnotetext{
${ }^{123}$ [2013] EWHC $3403(\mathrm{Ch})$ at [28].

124 [2012] EWCA Civ 865.

${ }^{125}$ Gallarotti [2012] EWCA Civ 865 at [11].
} 
however, he was found to have made 'no real contribution at all' towards the mortgage. ${ }^{126}$ His failure to rectify the disparity meant that 'the agreement for 50/50 sharing was at an end', ${ }^{127}$ and the Court of Appeal ultimately held that Mr Sebastianelli owned $75 \%$ of the beneficial interest as compared to $\mathrm{Mr}$ Gallorotti's 25\%, reflecting their financial contributions. Irrespective of the quantification issue, and in spite of Arden LJ's reluctance to engage explicitly with the case law, it is plain that Gallarotti $v$ Sebastianelli was a clear-cut case as regards establishment of the claimant's beneficial interest. Mr Gallarotti would easily have established an interest under Rosset by virtue of his direct contribution to the purchase price and probably the agreement as to beneficial ownership. Indeed, a panel of Justices refused Mr Gallarotti permission to appeal to the Supreme Court because his case did not 'raise an arguable point of law of general public importance'. ${ }^{128}$

Thompson $v$ Hurst is a more difficult case to categorise within the framework adopted by this article, ${ }^{129}$ largely because of a lack of clarity in the judgment of District Judge Spencer at first instance (as summarised by the Court of Appeal). It involved the shared home of the appellant and respondent couple, which was ultimately purchased by the respondent using a right-to-buy discount. The judge found that there was 'a common intention on the part of the appellant and the respondent, communicated to each other..., that they would buy the Property jointly'. ${ }^{130}$ The couple were nevertheless advised that because of the appellant's patchy employment history, the respondent should apply for the acquisition mortgage alone. The property was also purchased in the 'sole name' of the respondent. While the judge was

\footnotetext{
${ }^{126}$ Gallarotti [2012] EWCA Civ 865 at [13].

${ }^{127}$ Gallarotti [2012] EWCA Civ 865 at [26].

${ }^{128}$ Supreme Court, 'Permission to appeal results - November 2012'

$<$ http://www.supremecourt.gov.uk/docs/permission-to-appeal-1211.pdf $>$ at 4 .

${ }^{129}$ [2012] EWCA Civ 1752.

${ }^{130}$ Thompson [2012] EWCA Civ 1752 at [8] (Etherton LJ, paraphrasing para [14] of Judge Spencer's judgment).
} 
seemingly 'satisfied...that there was a common intention that the appellant was to have a beneficial share in the Property' notwithstanding the change of plan regarding the legal ownership, ${ }^{131}$ in the very next paragraph she mysteriously held that 'there was no common intention about the beneficial aspect because neither of them thought about it'. ${ }^{132}$ In the Court of Appeal, Etherton LJ confessed to having 'some difficulty in understanding' the judge's conclusion that there was a common intention as to shared ownership given her finding that the parties had given no thought to the beneficial ownership, ${ }^{133}$ although he was unable to disturb it. Etherton LJ also described the judge's decision as one that the common intention 'was to be inferred' from their original intention about shared legal ownership, in spite of the presence of express discussions. ${ }^{134}$

It may be that while express discussions took place as to the legal ownership of the property in Thompson, the judge somehow found that there was no express discussion relevant to the equitable ownership in the light of the decision to alter the transaction. While on this analysis a novel outcome could have been reached as compared to Rosset since the judge declared that the (eventual) appellant had a 10\% share, the distinction between the types of discussion seems a remarkably fine one. Given the suggestion that express discussions of some sort took place, and the possibility that the judge meant merely that the parties had given no thought to the quantum of the equitable interests, it seems likely that Thompson can be seen as consistent with Rosset in spite of the apparent absence of direct financial contributions either to the deposit or the mortgage on the part of the appellant. In any event, the appeal ultimately concerned the quantification of the appellant's beneficial interest

\footnotetext{
${ }^{131}$ Thompson [2012] EWCA Civ 1752 at [9] (Etherton LJ, paraphrasing para [15] of Judge Spencer's judgment).

${ }^{132}$ Thompson [2012] EWCA Civ 1752 at [9] (Etherton LJ, quoting directly from para [16] of Judge Spencer's judgment).

${ }^{133}$ Thompson [2012] EWCA Civ 1752 at [23].

${ }^{134}$ Thompson [2012] EWCA Civ 1752 at [23].
} 
(specifically his unsuccessful claim that it should be $50 \%$ because of the original intention to put the property in joint names), and there was no cross-appeal as to whether he should have any beneficial interest at all. Thompson is not, therefore, a strong authority for the proposition that the Rosset restrictions no longer apply to 'sole name' cases.

Taken together, however, Gallarotti and Thompson appear to suggest that at least a Jones-inspired approach can lead to a successful claim by a legal non-owner in the context of both conjugal and non-conjugal personal relationships.

\section{(iii) UNSUCCESSFUL COURT OF APPEAL CLAIMS}

Not all legal non-owners have been so successful before the Court of Appeal as the claimants in Gallarotti and Thompson. In Geary v Rankine, ${ }^{135} \mathrm{Mr}$ Rankine had moved from the home he shared with Mrs Geary in London to Halifax in order to run the guest house of which he was the legal owner and for which he had provided the purchase price. After a short time Mrs Geary moved there to assist him. It was seemingly common ground that he limited the amount of provision he made for her beyond housekeeping money because she was initially still married to a third party and he feared claims on any such provision by her husband and the children of that marriage. Mrs Geary asserted that when she questioned him about her future security and that of their son, Mr Rankine would say it was best for the business to remain in his "sole name' so that she could build it up again if he went bankrupt, and that eventually he would give no response to such questions or give a non-committal one.

Mrs Geary's counsel conceded that no relevant common intention existed at the time the guest house was purchased, but submitted that the common intention of the parties had subsequently changed. Lewison LJ emphasised that there must be a genuine common

\footnotetext{
${ }^{135}$ [2012] EWCA Civ 555.
} 
intention, 'that is, an intention common to both parties'. ${ }^{136} \mathrm{He}$ considered it an 'impermissible leap' to move from finding a common intention that the parties should run a business together to one that they were both beneficial owners of a business property for which one of them had paid. ${ }^{137}$ Lewison LJ's analysis attaches significance both to 'who pays for what ${ }^{138}$ and also to express discussions, suggesting that the Rosset factors ultimately came to the fore even in the post-Jones era at least in a quasi-commercial case. He was unconvinced that Mr Rankine had any intention that Mrs Geary should have an interest. He had refused to 'recognise' her until she got divorced for reasons that Lewison LJ considered to be rational, and she had not done so until six years after the property was acquired. ${ }^{139}$ Lewison LJ also pointed out that Mr Rankine was deliberately non-committal when she asked about her future security, which was again 'inconsistent with an intention on Mr Rankine's part that Mrs Geary should have a beneficial interest'. ${ }^{140}$ Unfortunately for Mrs Rankine, whose case was not a particularly strong one, this analysis provides an interesting contrast to the 'excuse' cases pre-dating Stack in which interests were successfully claimed, ${ }^{141}$ and is a consequence of an attempt to focus literally on common intention that Stack and Jones required. Geary is an important reminder, reassuring to those concerned about uncertainty and unpredictability in this area of the law, that even where Stack and Jones have an effect for claimants seeking to assert or increase beneficial interests it is not necessarily a liberalising one.

\footnotetext{
${ }^{136}$ Geary [2012] EWCA Civ 555 at [21] (emphasis in the original).

${ }^{137}$ Geary [2012] EWCA Civ 555 at [22].

${ }^{138}$ Cf. Stack v Dowden [2007] UKHL 17 at [60] (Lady Hale).

${ }^{139}$ Geary [2012] EWCA Civ 555 at [22].

${ }^{140}$ Geary [2012] EWCA Civ 555 at [22].

${ }^{141}$ See, eg, Eves v Eves [1975] 1 WLR 1338 CA, and S Gardner 'Rethinking Family Property' (1993) 109 LQR 263 at 265 for strong criticism of such cases.
} 
Smith $v$ Bottomley was another rare post-Jones Court of Appeal decision in which a claimant went away without a beneficial interest in the relevant property. ${ }^{142}$ Two of the parties were on-off cohabitants and fiancé(e)s, and Ms Smith had been engaged in Mr Bottomley's 'militaria' business. While the case raised many issues, the pertinent claim in the Court of Appeal was that Ms Smith had a beneficial interest in a barn that the parties intended to develop into a new family home, although they separated without it ever really being used as such. She claimed her interest on the basis of 'a promise or promises' made to her by Mr Bottomley. ${ }^{143}$ The complicating factor was that the property had been conveyed into the name of a company incorporated and controlled by Mr Bottomley. Mr Bottomley had paid the deposit, and the company had paid the balance of the purchase price and funded the renovations to the barn. The judge had held that Ms Smith did have a beneficial interest in the barn, though his findings were conflicting and were criticised by the Court of Appeal. Sales J, giving the lead judgment in the appellate Court, held that:

'...unless it can be said that the Company shared responsibility with Mr Bottomley for the relevant promise regarding ownership of the Barn and that Ms Smith relied to her detriment in a serious way upon such promise by the Company, there is no good ground on which it can be said that Ms Smith has the benefit of an equitable interest which she can assert against the Company as the legal owner of the Barn'. ${ }^{144}$

He emphasised that the only promise found by the judge to have been made by Mr Bottomley occurred before the company had been incorporated, and that in any case the alleged detrimental

\footnotetext{
${ }^{142}$ [2013] EWCA Civ 953, [2013] 2 P \& CR DG25.

${ }^{143}$ Smith [2013] EWCA Civ 953 at [2].

${ }^{144}$ Smith [2013] EWCA Civ 953 at [57].
} 
reliance (consisting of an agreement to marry and giving up of alternative accommodation) also effectively pre-dated the company. Smith is therefore of little help in enumerating the factors relevant to a common intention as between two cohabitants, though it may produce a resurgence in queries about detrimental reliance as an alternative means of defeating claims.

While Geary and Smith both had clear commercial elements in addition to being concerned with personal relationships, both were also genuine contests between cohabitants and it is not particularly clear that their claimants' failures to establish an interest were caused by a reluctance on the part of the Court to favour Stack/Jones factors over Rosset factors. An argument that such a reluctance is present can more easily be sustained in respect of Smith, but any such impression seems to have been created by the manner in which the case was pleaded. In any event, the outcomes of the two cases (as distinct from their legal analyses) do little to advance the claim that the Rosset criteria no longer apply in the light of Jones.

\section{(iv) SUCCESSFUL LOWER COURT CLAIMS}

As with all of their Court of Appeal counterparts, most of the successful lower court claims to a beneficial interest by legal non-owners following an apparent application of Jones would have been equally successful had Rosset been applied. This is true notwithstanding the fact that they represent successful Jones-inspired claims involving a variety of factual circumstances.

In $C P S$ v Piper, ${ }^{145}$ the husband (Graham) had originally acquired the whole legal title of Heathfields Farm from his former wife, Suzanne, as part of an arrangement they made when separating. In return, Graham paid a minimum of $£ 125,000^{146}$ to Suzanne towards a

\footnotetext{
${ }^{145}$ [2011] EWHC 3570 (Admin).

${ }^{146}$ Graham Piper claimed to have paid £160,000: Piper [2011] EWHC 3570 (Admin) at [31].
} 
new home for her. After a complex factual inquiry, Holman J found that Graham's current wife Janet had contributed $£ 30,000$ (held for her by her father) towards Graham's arrangement with Suzanne. Despite some serious inconsistencies in the evidence, the judge found that Graham and Janet 'each reasonably understood the other party to be manifesting an intention that Janet had a shared interest in Heathfields Farm, even if that was not consciously formulated in his or her own mind'. ${ }^{147}$ The payment of money, in substance towards a purchase price even though the consideration for the transfer was expressed to be Suzanne's 'natural love and affection' for Graham, ${ }^{148}$ means that Janet, like the claimant in Gallarotti, may have qualified for an interest even under the older Rosset principles, and indeed the judge implied that Janet could have had an interest proportionate to her financial contribution under a resulting trust had it been open to him to decide the case on that basis. ${ }^{149}$ This is true in spite of Dixon's downplaying the significance of the fact that Janet's conduct was the payment of money, emphasising that Jones was 'treated as the applicable authority' and asserting that 'it is difficult to see a return to the Rosset approach now that the genie is out of the bottle', ${ }^{150}$ an argument fortified by the references to Jones in appellate sole-owner cases considered above. ${ }^{151}$ In the end, Holman J concluded that the parties in CPS v Piper inferred a common intention that Janet had a 50\% interest in Heathfields Farm.

Another case with factual similarities to those considered in the previous section of the article, Rubin $v$ Dweck, involved an unsuccessful challenge by a husband's trustee in bankruptcy to the transfer of the matrimonial home from the husband's 'sole name' to that of

\footnotetext{
${ }^{147}$ Piper [2011] EWHC 3570 (Admin) at [78].

${ }^{148}$ Piper [2011] EWHC 3570 (Admin) at [14].

${ }^{149}$ Piper [2011] EWHC 3570 (Admin) at [72] (Holman J)..

${ }^{150}$ M Dixon 'Editor's notebook: The still not ended, never-ending story' [2012] Conveyancer \& Property Lawyer 83 at 84 (emphasis in the original).

${ }^{151}$ M Dixon Modern Land Law, (London: Routledge, $8^{\text {th }}$ edn, 2012) pp 170-74.
} 
the wife. ${ }^{152}$ One issue to be decided was whether the wife had a beneficial interest in the home at the time it was purchased. All of the purchase money for the house was provided by the wife's mother, and the Registrar found that the mother had intended the purchase money to be a gift to the husband and the wife equally. The Registrar held that the purpose of the gift and the use of it for that purpose, coupled with the fact that the wife contributed to the purchase price via the gift, meant that 'it is to be inferred...that there was a common intention to share the beneficial interest equally' at the time of the transfer. ${ }^{153} \mathrm{He}$ accepted that the house was put into the husband's name in case he needed to use it as security for small business loans. When assessing the bona fide nature of the parties' later agreement to transfer the house into the name of the wife, the Recorder focused on the Insolvency Act rather than any argument that the husband retained a beneficial interest after the transfer. As in Piper, however, the result in Rubin as regards the original purchase probably would have been defensible following Rosset, even if the principles outlined were clearly influenced by at least Stack.

The Northern Irish case of Bank of Scotland v Brogan, ${ }^{154}$ by contrast, did not involve direct financial contributions by the legal non-owner. Nevertheless, Deeny J significantly cited several factors supporting his conclusion that the defendant husband and wife had a common intention that the legal non-owning wife was to have an interest in their pre-marital and marital home. One of these, consistently with Rosset, were the husband's 'saying that what was hers was his and his hers', albeit in a 'light-hearted tone'. ${ }^{155}$ But the judge considered that comments such as the husband's 'might well fall short of being enough to

\footnotetext{
${ }^{152}$ [2012] B.P.I.R. 854 (Ch).

${ }^{153}$ Rubin [2012] B.P.I.R. 854 (Ch) at [71] (Mr Registrar Jones).

${ }^{154}$ [2012] NICh 21. See H Conway, 'Constructive trusts and the family home (yet again)' [2013] Conveyancer \& Property Lawyer 538 for discussion of the case.

${ }^{155}$ Brogan [2012] NICh 21 at [31].
} 
displace the exclusive legal title to the property of the first defendant' if it stood alone. ${ }^{156} \mathrm{He}$ therefore bolstered his finding with reference to a number of other features of the case, including the wife's financial contribution to the improvement of the property, the fact of eventual marriage, which in his view 'indicates a higher degree of commitment between the parties than merely a decision to live together and...a greater likelihood that property was to be jointly owned', ${ }^{157}$ the wife's help on the husband's farm and her care for 'her ailing mother-in-law'. ${ }^{158}$ The judge then proceeded separately to consider the quantum of the wife's interest (reaching a conclusion that she was entitled to a half share), which seemingly confirms that the preceding analysis related to the establishment of that interest. It is interesting that the judge's assessment of the husband's remarks is arguably more restrictive than that necessitated by Lord Bridge, even if Deeny $\mathrm{J}$ went on to adopt an holistic analysis consistent with a Jones-inspired approach unrestrained by Rosset. Nevertheless, once again the result in the case could still be seen as consistent with Rosset, and the case does not provide conclusive evidence that the law has moved on in Northern Ireland or beyond.

\section{(v) 'UNSUCCESSFUL' LOWER COURT CLAIMS}

In Patel v Vigh, Mr Patel's claim to a beneficial interest in the home that had been vested in the 'sole name' of his deceased cohabitant (Mrs Vigh) failed. ${ }^{159}$ Judge Halpern QC rejected the claim largely because of difficulties with the available evidence, and particularly that of Mr Patel himself. The judge found insufficient evidence of the claimed improvements made

\footnotetext{
${ }^{156}$ Brogan [2012] NICh 21 at [31].

${ }^{157}$ Brogan [2012] NICh 21 at [34].

${ }^{158}$ Brogan [2012] NICh 21 at [37].

${ }^{159}$ [2013] EWHC 3403 (Ch). He was also unsuccessful in seeking provision out of her estate under the Inheritance (Provision for Family and Dependants) Act 1975.
} 
to the property by $\mathrm{Mr}$ Patel, financial contributions at the time of purchase and by way of mortgage instalments that he made, or financial and non-financial contributions to Mrs Vigh's café business. $^{160}$

In spite of his conclusions on the facts, it is significant for present purposes that Judge Halpern considered improvements and business contributions to be at all relevant to the establishment of a beneficial interest, both of which appear inconsistent with Rosset. This is true even though the judge doubted that improvements made before Mrs Vigh had used her right-to-buy discount (and therefore while she was still a council tenant) could give rise to a beneficial interest and noted the possibility that the claimant's alleged business contributions were 'so remote' from the property that they could not give rise to a beneficial interest. ${ }^{161}$

Finally, the context of Aspden $v$ Elvy involved Outlaithe Farm, which included Outlaithe Barn. ${ }^{162}$ In contrast to many of the lower court cases considered in this section, it concerned a genuine dispute between former cohabitants, which essentially related to the barn. The judge refused to find that the parties had a common intention to share the farm at the time it was acquired, since the non-owner Ms Elvy had paid none of the outgoings and (by her own admission) 'there were no express discussions as to any interest she might have'. ${ }^{163}$ References to 'our house' made by the parties were considered insufficient, ${ }^{164}$ and Judge Behrens' approach on this point has much in common with Rosset. The judge was prepared to accept that it was 'at least arguable' that work on the farm carried out by Ms Elvy post acquisition 'gives rise to an inference that the common intention of the parties had changed so

\footnotetext{
${ }^{160}$ Patel [2013] EWHC 3403 (Ch), [29].

${ }^{161}$ Patel [2013] EWHC 3403 (Ch), [29].

${ }^{162}$ [2012] EWHC $1387(\mathrm{Ch})$. See J Lee “"And the waters began to subside”: Imputing intention under Jones v Kernott' [2012] Conveyancer \& Property Lawyer 421 for discussion of the case.

${ }^{163}$ Aspden [2012] EWHC 1387 (Ch) at [107] (Judge Behrens).

${ }^{164}$ Aspden [2012] EWHC 1387 (Ch) at [107] (Judge Behrens).
} 
that it was intended that Ms Elvy should have some interest' ${ }^{165}$ Judge Behrens was also influenced, however, by 'the caution expressed by Sir John Chadwick' in the restrictive case of James $v$ Thomas about such scenarios, ${ }^{166}$ implying that Jones has had a limited role in developing the law on this point. Ultimately, however, Judge Behrens did not 'find it necessary to determine' whether Ms Elvy had an interest in the farm, ${ }^{167}$ seemingly because the dispute centred around the barn. As with the unsuccessful Court of Appeal claims, it is difficult to sustain an argument that the failure of the claims in Patel and (considered thus far) in Aspden were caused by a focus on Rosset at the expense of Jones. Both Judge Halpern and Judge Behrens would apparently have been content to move beyond Rosset had the evidence in their respective cases been stronger.

Whatever the perceived relevance of Jones $v$ Kernott, however, none of the judicial conclusions on the acquisition of a beneficial interest by a legal non-owner analysed in this section of the article clearly moved beyond Rosset in terms of their outcome. As will nevertheless become clear, our discussion of Aspden $v$ Elvy must be continued in the next section, since Judge Behrens arguably reached another conclusion that was inconsistent with Rosset.

\section{(c) A novel outcome?}

In spite of the restrictive approach taken in relation to the farm in Aspden $v$ Elvy, Judge Behrens' analysis as regards the barn could (rather schizophrenically) place the case in the

\footnotetext{
${ }^{165}$ Aspden [2012] EWHC $1387(\mathrm{Ch})$ at [110].

${ }^{166}$ Aspden [2012] EWHC 1387 (Ch) at [111].

${ }^{167}$ Aspden [2012] EWHC 1387 (Ch) at [112].
} 
third category considered at the outset of this article by permitting an outcome inconsistent with Rosset in the light of Jones.

Judge Behrens found that Mr Aspden did not retain any interest in the barn when he originally transferred it into Ms Elvy's name, ostensibly for reasons relating to creditors and inheritance tax. The judge held that there was 'nothing in Mr Aspden's words or conduct that would entitle [Judge Behrens] to infer that there was any common intention that he should retain any interest in Outlaithe Barn'. ${ }^{168}$ Significantly, however, Judge Behrens did find that Mr Aspden made considerable financial and non-financial contributions to the conversion of the barn. The judge held that, in spite of the absence of express discussions, Mr Aspden had been successful in demonstrating that 'the common intention of the parties (objectively ascertained) was that he should have an interest as a result of the substantial contributions both in financial and physical terms that he made to the works'. ${ }^{169}$ Mr Aspden had not intended his contributions to be gifts made in recognition of his relationship with Ms Elvy and her status as mother of his children, and he had hoped to live in the barn once the conversion was complete. Indeed, it was found that as a result of his expenditure, his only other effective source of accommodation would have been a caravan. Via a process of imputation, Judge Behrens found $\mathrm{Mr}$ Aspden to have an interest of $25 \%$ in the property, representing a 'fair return' on his financial and physical investment. ${ }^{170}$

In holding that Mr Aspden had established an interest in the barn, the judge appears to have moved on from the Rosset criteria and taken an holistic approach, since the financial contributions made by $\mathrm{Mr}$ Aspden related not to its acquisition but its improvement. This is true even if Mr Aspden could not realistically have been expected to make direct financial

\footnotetext{
${ }^{168}$ Aspden [2012] EWHC $1387(\mathrm{Ch})$ at [118].

${ }^{169}$ Aspden [2012] EWHC $1387(\mathrm{Ch})$ at [123].

${ }^{170}$ Aspden [2012] EWHC $1387(\mathrm{Ch})$ at [128].
} 
contributions to the 'acquisition' of the barn at the relevant time, since he had originally acquired it by himself and then chosen to transfer it to Ms Elvy. The matter is complicated by the judge's assertion that he was 'fortified" ${ }^{171}$ in his conclusion by the pre-Rosset decision in Bernard $v$ Josephs, which was in fact a 'joint names' case. ${ }^{172}$ In particular, Judge Behrens cited Griffiths LJ's remarks in Bernard to the effect that '[i]t might in exceptional circumstances be inferred that the parties agreed to alter their beneficial interests after the house was bought', ${ }^{173}$ and his example of a legal non-owner who afterwards 'used a legacy to build an extra floor to make more room for the children'. ${ }^{174}$ In Griffiths LJ's view the 'obvious inference' in those circumstances would be an agreement that the legal non-owning partner 'should acquire a share in the greatly increased value of the house produced by her money'. ${ }^{175}$ Judge Behrens held that 'the contributions made by Mr Aspden are akin to the case envisaged by Griffiths LJ' ${ }^{176}$

The complicating factor is that the citation of Bernard may itself undermine the suggestion that Judge Behrens was moving on from Rosset. The judge had himself found Bernard to be consistent with Rosset in the pre-Jones (but post-Stack) case of Hopton $v$ Miller ${ }^{177}$ albeit that on the facts of that case the legal owner had paid for all the relevant repairs and improvements himself and the claimant could not legitimately assert a beneficial interest. ${ }^{178}$ Moreover, even in the ungenerous post-Stack case of James $v$ Thomas, Sir John

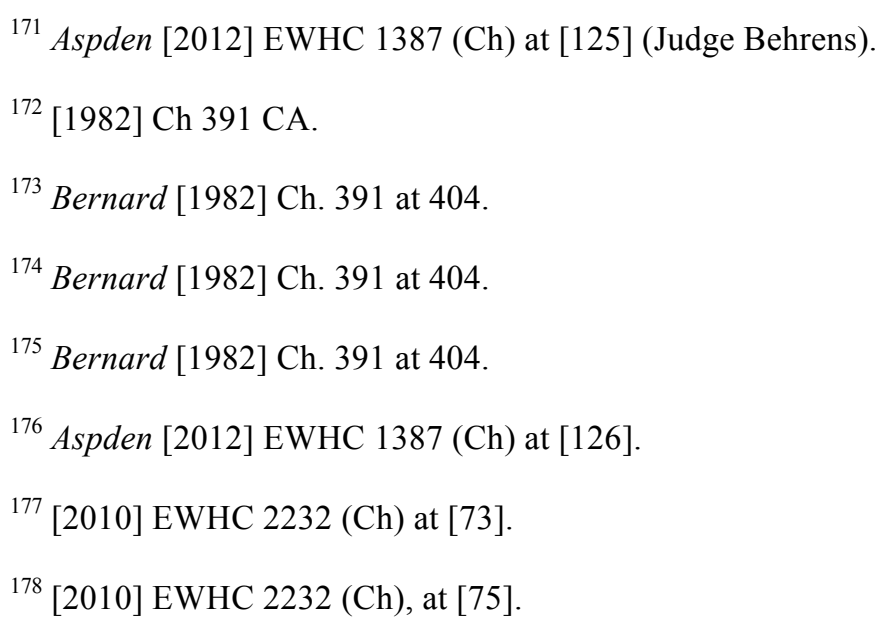


Chadwick had cited Griffiths LJ's remarks in Bernard in support of his conclusion that 'in the absence of an express post-acquisition agreement, a court will be slow to infer from conduct alone that parties intended to vary existing beneficial interests established at the time of acquisition' ${ }^{179}$ Sir John's conclusion was approved in the subsequent post-Stack decision in Morris $v$ Morris ${ }^{180}$ and in turn in the restrictive post-Jones case of Re Ali. ${ }^{181}$ It is also possible that Griffiths LJ's 'exceptional circumstances' could be matched with Lord Rosset's 'extremely unlikely' scenario where something less than a financial contribution would 'do'.

However, it is not clear that Bernard and Rosset are consistent with each other, since Lord Bridge did not expressly include indirect improvement-based financial contributions in his methods of inference. Indeed, his Lordship said explicitly in Rosset that 'a common intention by spouses that a house is to be renovated as a "joint venture" is not something that 'throws any light on their intentions with respect to the beneficial ownership of the property'. ${ }^{182}$ In his view, even the considerable manual work of the claimant in Eves $v$ Eves $^{183}$ 'fell far short of such conduct as would by itself have supported the claim in the absence of an express representation by the male partner that she was to have such an interest' ${ }^{184}$ It would admittedly be possible to distinguish financing improvements from carrying them out (though Judge Behrens did not draw such a sharp dividing line), and the recognition of a contribution leading to an increase in the value of a property is at most a

\footnotetext{
${ }^{179}$ [2007] EWCA Civ 1212 at [24].

${ }^{180}$ [2008] EWCA Civ 257 at [19] (Sir Peter Gibson).

${ }^{181}$ [2012] EWHC 2302 (Admin) at [106] (Dobbs J). See the text to $\mathbf{n} 86$ above.

${ }^{182}$ Rosset [1991] 1 AC 107 HL at 130.

${ }^{183}$ [1975] 1 WLR 1338 CA.

${ }^{184}$ Rosset [1991] 1 AC 107 HL at 133. See also Pettitt $v$ Pettitt [1970] AC 777 HL and C Harpum, S Bridge \& M Dixon Megarry \& Wade: The Law of Real Property (London: Sweet \& Maxwell, $8^{\text {th }}$ edn, 2012) at [1125](1)(iii). Cf. Matrimonial Proceedings and Property Act 1970, s 37.
} 
modest extension to the Rosset criteria as compared to recognising indirect financial or wholly domestic contributions. In spite of this, a combination of Stack and Jones could ultimately be said to have diverted attention from the strictures of Rosset and legitimised direct recourse in Aspden to older authority more liberal than it in a manner that affected the outcome of the case.

In the light of the number of cases producing orthodox results, the degree of internal incoherence caused by Judge Behrens' own conservative conclusion on the farm and the doubts about whether the recognition of improvements really is novel, however, Aspden is not a particularly unequivocal sign of developments to come in dispensing with Rosset. It could be unfair to say that the Court of Appeal and the lower courts have already squandered the apparent opportunity to consign Rosset to history, even if they could be criticised for their lack of clarity on the point, since in the cases arising so far they did not always need to move beyond Rosset in order to open the door to the legitimately liberal approach to quantification following Stack and Jones. But on the basis of the authorities considered in this article a conservative approach could easily take root, such that another Supreme Court decision is necessary conclusively to remove the straitjacket of Rosset from the establishment of an interest in a shared home via a constructive trust.

\section{CONCLUSION}

This article has analysed what will in all likelihood become a fraction of the case law where Jones $v$ Kernott is relevant. What it has shown is that the Supreme Court in that case, building on the earlier decision in Stack $v$ Dowden in a frustratingly opaque manner, appeared to invite the lower courts to move beyond the restrictive Rosset criteria in cases where a party to a personal relationship seeks to establish a beneficial interest in a shared home, arguably 
leaving the lower courts with a conflict of obiter dicta at the highest judicial level that has caused a considerable lack of clarity in some subsequent decisions, particularly in the High Court. Despite encouraging rhetoric (along with some absences of discouraging rhetoric) about the reach of Jones in cases from a wide range of contexts, judges in both the High Court and the Court of Appeal have been largely unable, but occasionally unwilling, to accept the Supreme Court's invitation in a manner affecting outcome as yet, though in any event caution was perhaps inevitable in the light of the stare decisis principle. ${ }^{185}$ It is unclear whether the paucity of reported cases with the potential to facilitate a novel outcome, which admittedly reduces the scope for those decided cases to be regarded as unjust, can be explained by mere coincidence, a reluctance to litigate given the uncertainty on whether a legal non-owner will gain an interest at all, or a genuine absence of difficulty in meeting the Rosset criteria on the part of most modern legal non-owning cohabitants. ${ }^{186}$

Whatever the reason for the trend in fact patterns reaching the Court of Appeal and the lower courts, it means that a Supreme Court case dealing squarely with a 'sole legal owner' scenario is likely to be required before the vexed question considered in this article can be resolved. Even if the law has been liberated from Rosset, moreover, the Supreme Court may still have to clarify precisely how a common intention is to be inferred directly from conduct

\footnotetext{
${ }^{185}$ See M Harding and I Malkin, 'The High Court of Australia's Obiter Dicta and Decision-Making in Lower Courts' (2012) 34 Sydney Law Review 239 for a discussion of the significance of appellate obiter dicta in Australia.

${ }^{186}$ Judging by the level of news coverage, the case of Curran v Collins [2013] EWCA Civ 382 (on which only the judgment concerning position to appeal is available at the time of writing) could become the new archetypal illustration of the legal non-owner's difficulties. See, eg, K O'Callaghan “"Unfair” laws for cohabiting couples highlighted again' (BBC News Online, 6 February 2013) <http://www.bbc.co.uk/news/business-21337154>; V Ward 'Cohabiting laws unfair on women, says judge' (The Daily Telegraph, 24 January 2013); L Tobin, 'Get it write if you cohabit' (The London Evening Standard, 5 February 2013).
} 
beyond Lord Bridge's criteria, and the particular factual configuration of cases may become more influential than it currently appears to be. Given the current political climate, ${ }^{187}$ a relevant Supreme Court decision somehow seems more likely than a move to provide a statutory remedy for a non-legal-owning cohabitant, even if such a scheme would be much more desirable.

${ }^{187}$ Cf. the Cohabitation Rights Bill 2013-14, a Private Member's Bill introduced into the House of Lords by the Liberal Democrat peer Lord Marks of Henley-on-Thames in October 2013. 